Golden Gate University School of Law GGU Law Digital Commons

Publications

Faculty Scholarship

1968

\title{
Good Offices as a Peaceful Means of Settling Regional Differences
}

\author{
Sompong Sucharitkul \\ Golden Gate University School of Law, ssucharitkul@ggu.edu
}

Follow this and additional works at: http://digitalcommons.law.ggu.edu/pubs

Part of the International Law Commons

\section{Recommended Citation}

A chapter in: International Arbitration, Liber Amicorum for Martin Domke, pp. 338-347 (Pieter Sanders, ed., Martinis Nijhoff 1967).

This Book Chapter is brought to you for free and open access by the Faculty Scholarship at GGU Law Digital Commons. It has been accepted for inclusion in Publications by an authorized administrator of GGU Law Digital Commons. For more information, please contact jfischer@ggu.edu. 
SOMPONG SUCHARITKUL

Ministry of Foreign Affairs Bangkok

\section{Good Offices as a Peaceful Means of Settling Regional Differences}

Pacific settlement of disputes between States has formed a significant part of international law and order. It is a subject which has occupied the thoughts of many a statesman and has found expression in the writings of contemporary jurists. ${ }^{1}$ The United Nations Charter contains an important Chapter on Pacific Settlement of Disputes, Article 33 of which provides: ${ }^{2}$

The parties to any dispute, the continuance of which is likely to endanger the maintenance of international peace and security, shall, first of all, seek a solution by negotiation, enquiry, mediation, conciliation, arbitration, judicial settlement, resort to regional agencies or arrangements, or other peaceful means of their own choice.

Much has been written about the various methods of pacific settlement of disputes specifically mentioned above. ${ }^{3}$ But very little literature can be found on "other peaceful means of their own choice." It is the purpose of this modest essay thus to supplement to some extent the missing link by an effort to throw some light on one of the pacific procedures not enumerated in the Charter, but is nonetheless growing in usefulness and popularity over the recent years. The present study will therefore be concentrated upon the procedure of "Good Offices" as a peaceful means of adjusting regional differences. As this paper is being dedicated to a personal friend, it will not be out of order to add a personal touch by making references to two almost unrecorded cases, where the pacific procedure of "good offices" has been utilized. These two cases concern the negotiations between Thailand and Cambodia with the good offices of the Secretary-General of the United Nations, and the Good Offices extended by the Government and Minister of Foreign Affairs of Thailand to bring about normalization of relations between Malaysia and Indonesia on the one hand and Malaysia and the Philippines on the other. With both these cases the present reporter has been personally associated.
I. GENERAL NATURE AND SCOPE OF "GOOD OFFICES"

The expression "good offices" is used to denote a procedure whereby a third party or State either on its own initiative or upon request seeks through diplomatic means to bring the Parties to the disputes to a conference table to resume direct negotiations or to agree on a method of pacific settlement with the view to bringing an end to the existing conflict.

"Good offices" is often confused with "mediation." A line of distinction is thinly drawn between the two procedures. "Good offices" implies a more discreet action, limited to initiating direct negotiations between the parties concerned without active participation, whereas a mediator generally takes a more active part in the discussion and is often expected to suggest some solutions to the problem.

This terminology "good offices" has been in diplomatic as well as judicial usage for some time. Thus, Chief Justice Marshall in the Schooner Exchange v. M'Faddon (1812) referred to it in this fashion:4

The world being composed of distinct sovereignties, possessing equal rights and equal independence, whose mutual benefit is promoted by intercourse with each other, and by an interchange of those good offices which humanity dictates and its wants require, all sovereigns have consented to a relaxation, in practice, in cases under certain peculiar circumstances, of that absolute and complete jurisdiction within their respective territories which sovereignty confers.

Pradier-Fodéré in the late XIX century gave an accurate description of the role of "good offices" as a means of settling international disputes. He wrote: 5

Le rôle de l'Etat ou des Etats tiers qui interposent leurs bons offices, consiste à disposer les parties contendantes au règlement pacilique de leur dilférend, à préparcr leur rapprochement, à faciliter les négociations. Ils aident les parties à cutamer les pourparlers, ils l'appliquent a bien poser les questions; ils mettent les négociateurs en présence; ils donnent de bienveillants conseils, propres à apaiser les ressentiments; ils recommandent certaines mesures, proposent les tempéraments utiles pour arriver à un arrangement amiable, à une transaction; ils exercent leur influence morale pour obtenir que l'une et l'autre partie modèrent leurs prétentions excessives d'une façon juste et équitable. Mais là se borne le concours obligeant de l'Etat ou des Etats tiers qui pretent leurs bons offices; ils n'a pas d'autre objet que de faciliter aux Puissances entre lesquelles un différend existe le moyen de nouer l'une avec l'autre des négociations, sans participer à ces derniers.

Good offices may be very extensive in the services and facilities rendered but are slightly short of actual participation in the process of 
negotiation. This point was clearly emphasized by Fauchille, who said: 6

Une tierce puissance peut juger bon d'offrir son entremise pour faire un différend entre deux Etats. Elle peut intervenir en proposant ses bons offices. Ceux-ci peuvent aussi etre réclamés d'un tiers Etat par l'une ou l'autre ou par les deux parties en litige. Les bons offices sont la forme la moins accentuée de l'immixtion. - Ils consistent, de la part d'une puissance tierce, à uscr de son influence morale pour renouer entre les Etats en conflit les négociations rompues, pour les amener à se faire des concessions réciproques. L'Etat qui offre ses bons offices ne prend pas une part directe aux négociations ou aux arrangements qui peuvent intervenir.

Treaties and international conventions tend to include "good offices" in the same grouping with "mediation." Thus the "Pact of Bogota" I948, which is an American Treaty on Pacific Settlement, deals with Procedures of Good Offices and Mediation together under Chapter II. It might be convenient to say that "Good Offices" stops where mediation begins, if the degree of participation by the middle man or the go-between is taken into consideration. There may as such be border line cases where the two procedures are hardly distinguishable.?

The relevant provisions of the Bogota Pact on good offices and mediation run as follows:

\section{Article IX}

The procedure of good offices consists in the attempts by one or more American Governments not parties to the controversy, or by one or more eminent citizens of any American State which is not a party to the controversy, to bring the parties together, so as to make it possible for them to reach an adequate solution between themselves.

\section{Arlicle $X$}

Once the parties have been brought together and have resumed direct negotiations, no further action is to be taken by the states or citizens that have offered their good offices or have accepted an invitation to offer them; they may. however, by agreement between the parties, be present at the negotiations.

"Mediation," on the other hand, is defined by Article XI as submission of the controversy to an outsider by mutual agreement between the parties concerned. The role of the mediator is to assist the parties in the settlement of the controversies in the simplest and most direct manner, avoiding formalities and seeking an acceptable solution. ${ }^{8}$

The Hague Convention, No. I, of October 28, 1907 also contains stipulations which appear to place good offices and mediation in comparable positions. Article 2 provides: "En cas de dissentiment grave ou de conjlit, avant d'en appeler aux armes, les Puissances contractantes conviennent d'avoir recours, en tant que les circonstances le permettront, aux bons offices ou à la médiation d'une ou de plusieurs Puissances amies." Under the Hague Convention, however, the role of a mediator or a country offering good offices cannot be assumed by one of the parties to the disputes. In any event, an offer of good offices or mediation or any similar assistance shall not be regarded by the parties involved in the dispute as an unfriendly or less friendly act.

\section{GROWING TREND IN FAYOUR OF "GOOD OFFICES"}

The procedure of good offices has steadily gained in popularity, particularly in regard to regional disputes or the more localized differences as opposed to world-wide or global conflicts, which would admit of very few methods of pacific settlement. While good offices seems to be more and more frequently resorted to by States, less and less reliance is placed on judicial settlement. This is understandable in view of the arbitrary character of the compulsory jurisdiction system and the apparent lack of justice and want of equitable solutions readily visible from recent judicial decisions. Thailand's reservation to the decision of the International Court of Justice in the Temple of Phra Viharn Case in 1962 testifies to the validity and logic of this inevitable tendency. The Court's decision in the South West Africa Cases this year further. confirms the trend away from volunary submission to judicialsettlement. Neither case inspires respect for the wisdom of the World Court. The current trend appears to be well in favour of more consensual modes of adjustment such as arbitration or mediation. "Good Offices" stands out as the most convenient method of adjusting local or regional differences. There have been several illustrations of its successful operation. For present purposes, two "causes célebres" will receive our brief attention.

\section{THAILAND-CAMBODIA: NEW YORK AGREEMENTS Ig60}

In the fall of 1960 , the late Mr. Dag Hammarskjöld, then SecretaryGeneral of the United Nations, together with the late Ambassador Engen of Norway, extended and rendered their good offices to Thailand and Cambodia during their bilateral negotiations at the Headquarters of the United Nations in the presence of the Secretary-General and Ambassador Engen at the request and with the agreement of the parties to the negotiations.

Mr. Hammarskjöld was not only present together with Ambassador 
Engen during the three formal meetings between the Thai and the Cambodian delegations in the Secretary-General's apartment on the 38 th floor of the United Nations Building, but he also made pertinent impartial observations on some of the matters under discussion, which assisted, and in some measure, facilitated the negotiations. The two delegations nevertheless held direct talks in the presence and with the good offices of the Secretary-General.

The nature and scope of the good offices in this case are of practical interest to all students of pacific settlement. The Secretary-General in his informal individual capacity provides necessary facilities for the two parties to carry on their negotiations, ranging from the room, a table with chairs, to interpretation services, since the Thai delegation spoke in English while the Cambodian preferred to speak in French. For this purpose, consecutive translation services were also provided as part of the good offices both during the three meetings and at other less formal sub-committee meetings. Apart from translation, an informal summary record of the proceedings of the Mectings was also kept by the Secretariat Officers in English as well as in French. Althougl the actual texts of the exchange of notes marking the conclusion of the negotiations were prepared by the respective parties, the exchange was executed also in the presence of the Secretary-General and his designated representative, Ambassador Engen.

It should be further noted in this case that the persons or organization rendering the good offices did in fact participate with the consent of both parties in the deliberations of the formal meetings. There were several informal direct negotiations in the meantime. But whenever a difficulty appeared insurmountable, the services of the SecretaryGeneral were not lacking. The parties were able in the end to reach some agreements on four separate matters which formed the subject of the exchange of letters concluded on December 15,1960 . The agreements concluded with the good offices of Mr. Dag Hammerskjöld concerned:

I. Activities of rebels and political refugees;

2. Surrender of common law criminals;

3. Suppression of unlawful acts along the border areas; and

4. Cessation of press and radio attacks.

At the conclusion of the final Meeting where the letters were signed and exchanged, the two Delegations expressed appreciation for the trouble the Secretary-General had taken to participate in the work in a personal way, for the efforts and contribution made by the Secretary-
General and Mr. Engen as well as other United Nations officers, who had assisted, facilitated and made possible the conclusion of four important agreements. Before the echoes of the jubilant feeling of gratitude and appreciation for the success of the good offices rendered could be widely heard, however, a tragic thing had occurred. The agreements concluded after so much toil and labour were suspended owing to Cambodia's persistent violations of its undertaking to refrain from making disparaging references against Thailand.

\section{IV: THE MALAYSIA-INDONESIA QUESTION T963-I966}

Since only the settlement aspect of the question will be examined here, it will suffice to give a very brief and cursory account of the substance of this complex question. The question is indeed complex because it centres upon and around Malaysia which came in to existence in August 1963, incorporating within it the territories of Singapore, Sarawak and Sabah. On the one hand, the Philippines had a claim on Sabah, whereas Indonesia, on the other, raised objection to the concept of Malaysia which engulfed Sarawak and Sabah, aliler North Kalimantan. While Indonesia and the Philippines continued their friendly ties, each of them had withheld recognition of the new State, Malaysia, diplomatic relations between Malaysia and the other two neighbours were thus severed. Thai Embassies in Manila and Djakarta had been asked to look after the interests of Malaysia, while the Royal Thai Embassy in Kuala Lumpur was taking care of the Philippines affairs and interests.

The Malaysia controversies grew in size and acuteness, as confrontation mounted in the frequency as well as in the height of hostilities. The Southern part of Southeast Asia was in a state of turmoil, and a predatory power from outside began to fish in troubled water.

Countries friendly to the three Southeast Asian nations felt the uneasiness of the disturbing situation. Japan and Thailand, being friends of the three nations involved, offered to extend their good offices. The Philippines, itself a direct party, endeavoured to find a solution through the concept of Maphilindo, a merger of all the three parties. But no solution was readily to be found which would be acceptable and satisfactory to all parties.

Japan's good offices culminated in the Tokyo Summit Meeting in June r964, where President Soekarno, Tunku Abdul Rahman and President Diosdado Macapacal also attended. No concrete solution was 
agreed upon, although Japan continued its good offices through diplomatic and other peaceful means.

The choice of country and personality to render good offices for the settlement of the growing problem was important as it might enhance the probability of a successful outcome. In the earlier case under review, Mr. Dag Hammarskjöld and the United Nations could be considered neutral with guaranteed impartiality as between Thailand and Cambodia. For the Malaysia question, a person or country qualified to offer good offices had to be a friend of the Southeast Asian family as well as enjoying the confidence and respect of Indonesia, Malaysia and the Philippines.

The Government of Thailand was a logical choice and Foreign Minister Thanat Khoman did have the confidence and respect of his three Southeast Asian friends. Thailand together with Malaysia and the Philippines belonged to the Association of Southeast Asia (ASA), a regional arrangement for economic cooperation and social and cultural development. Indonesia and Thailand were entertaining very close and cordial relations.

The good offices extended by the Government and Foreign Minister of Thailand dated back to the very beginning when it all started. Thailand as the connecting link in the ASA line of communications was able to maintain continuing contact between The Philippines and Malaysia. The Thai Embassy in Djakarta also had a role to play in the chain of communications between Malaysia and Indonesia. But the most vital figure was the Foreign Minister himself, who played a constructive part in the solution of the Malaysia problem.

His difficult mission was originally to bring the Foreign Ministers of the three countries together. This he did successfully in Bangkok, where the three Ministers held several meetings both directly and often with the presence and participation of the Thai Foreign Minister. The facilities accorded included guest houses and meeting rooms as well as necessary secretarial services. No interpretation was needed since the proceedings were conducted in English, although on a much later occasion the dialogues between the Malaysian and Indonesian Delegations were partly in their common native tongue.

As part of the good offices, the Foreign Minister sometimes had to be itinerant, visiting his colleagues who represented the parties directly involved at their capitals or elsewhere where private talks were held. A series of private bilateral consultations were held between the Thai Foreign Minister and each of the other Ministers at various times and places. They no doubt discussed the core of the problems and the various possible solutions and the steps and measures to implement the peaceful adjustment.

Meanwhile; fighting had erupted. The question of withdrawal of fighters was raised and discussed, and here again the services of Thailand were requested as part of the good offices to verify the withdrawal of the fighters at various check-points within the theatre of the suspended hostilities.

Even in the darkest days when all reasonable and practical solutions had been exhausted without much prospect of a pacific settlement, Thailand had never lost hopes, but kept on persisting in her perseverance to look for peaceful solution to the Malaysia question. Meanwhile, another difficult situation arose resulting in the independent existence of the sovereign State of Singapore, separate from Malaysia.

An opening was found after the Communist Coup attempt on September 30,1965 failed to take over Indonesia. This significant turn of events had contributed to the successful adjustment of the differences. Prior to that date, the PKI had consistently obstructed any constructive move towards reconciliation, because the Party stood to gain from internal confusion as well as from external turmoil. Bangkok again became the site for two historic meetings which brought an end to the three-year old conflict.

The Philippines and Malaysia had already reestablished consular relations in 1965 , but the prospect of resumption of diplomatic relations was not realistic until the election of President Marcos. The Philippine and Indonesian Delegations met in Bangkok in late April and early May 1966 and, availing themselves of the good offices of Thailand, were able to reach agreement on their respective positions regarding normalization of relations with Malaysia. Diplomatic missions between Malaysia and the Philippines were formally exchanged, following the Bangkok Meeting.

In late May Ig66, the Thai Foreign Minister played host to the visiting delegations from Indonesia and Malaysia. The leaders of the two delagations held direct talks in Bangkok. The host Government provicled necessary facilities as part of the good offices. The Thai Foreign Minister played an important role in finally bringing the parties together and contributed substantially to the successful conclusion of the long pending negotiations. The historic talk culminated in the signing of the Bangkok Agreement, which was subsequently confirmed in Djakarta. The Malaysia question has thus been resolved by the use of 
good offices of which Thailand's contribution was appreciated by the countries concerned, and by their friends who wished them well. Despite the major role played by Thailand in the adjustment of the outstanding differences, the Thai Foreign Minister has been very modest and discreet. His statesmanship, his diplomatic skill and the Asian wisdom of farsightedness have been highly rewarding. His good offices have certainly opened up a new vista of Southeast Asian cooperation, now that the members of the Southeast Asian Community have been put back on the basis of friendship and equal partnership in the family of free Asian nations.

\section{CONCLUSION}

The two cases reported above are indicative of the extent to which good offices as a procedure for pacific settlement have been used with creditable measure of success. Its use is more frequent in highly political controversies and in differences between neighbouring countries. Particularly in Asia, Africa and perhaps also in Latin America (Bogota Pact), resort to good offices as a peaceful means of adjusting regional differences is more widespread. As a pacific procedure for settling disputes, good offices offer the best assurance of a solution satisfactory to the parties concerned, being the least imposing form of interference. Indeed it has been rightly termed "interposilion conciliatrice," which is more readily available. The disputing authorities tend to be more receptive to accepting "good offices" of a friendly neighbour than other more imposing forms of pacific settlement. The absence of an element of compulsion which is replaced by gentle persuasion, and employment of tact, often lead to salutary results. The success or failure of "good offices" therefore depends to an appreciable extent on the skill and patience of the officer rendering the good offices. As the procedure continues to meet with more and more successes, it is to be expected that "good offices" will in the course of time supplant if not replace most other methods of pacific settlement including those enumerated in Article 33 of the Charter.

Attention should therefore be paid to this encouraging development, which nourishes a hope that given good will and understanding, there should be no differences that cannot be adjusted, nor disputes that mit of no just and equitable solution.

\section{Notes}

1. Sec e.g. Julius Stone, Legal Conirol of International Con/lict (London 1954) for a list of literature on the Development of Pacilic Procedures, see Louis B. Sohn, Cases and other Malerials on World Law (Brooklyn, 1950) pp. 1035I 102 .

2. The Charter was signed at San Francisco, June 26, 1945 and entered into force on October 24, 1945. Text supplied by the United Nations Secretariat.

- See eodrich, "The United Nations: Pacific Settlement of Disputes," American Political Science Review, XXXIX, p. 956, and Clyde Eagleton, "The Jurisdiction of the Security Council over Disputes," American Journal of International Law, XL, Pp. 513-533.

4. $(1812) 7$ Cranch 116 , at pp: $136-137$.

5. Pradier-Fodére, Trailé de droit international public europén et amtéricain. (1885-1906), No. 2588.

6. Fauchille, Traite de droil international public, Paris, (1921-1925), No. 932.

7. See Rapport Descamps, Conférence de la Paix de I899. Acles, p. 102. "Les bons offices peuvent être distingués à certains égards de la médiation. Pratiquement, ces moyens d'action se différencient moins par leur nature que par leur pénétration plus ou moins grande dans la sphère des rapprochements amiables. Souvent d'ailleurs l'un succède a l'autre et la Puissance tierce qui a noué des négociations entre des Etats en conflit est tout indiquée pour participer à ces négociations et parfois pour les conduire. Les actes diplomatiques n'insistent pas sur cette distinction."

8. Article XII also provides that "no report shall be made by the mediator and, so far as he is concerned, the proceedings shall be wholly confidential." 